\title{
The Effect of Calcination Temperature on the Electrochemical Performance of $\mathrm{ZnO}$ Coated $\mathrm{LiMn}_{2} \mathrm{O}_{4} / \mathrm{MWCNT}$ Nanocomposite Cathodes
}

\author{
A. Akbulut ${ }^{a, *}$, T. Centinkaya ${ }^{b}$, M.O. Guler $^{b}$ And H. Akbulut ${ }^{b}$ \\ ${ }^{a}$ Sakarya University, Dept. of Environmental Engineering, Esentepe Campus, 54187, Sakarya, Turkey \\ ${ }^{b}$ Sakarya University, Metallurgy and Materials Engineering, Esentepe Campus, 54187 Sakarya, Turkey \\ In this study, it is aimed to develop $\mathrm{LiMn}_{2} \mathrm{O}_{4} / \mathrm{MWCNT}$ nanocomposite cathode materials by using different \\ calcination temperatures $\left(300,500,700^{\circ} \mathrm{C}\right)$. The aim of using MWCNTs in the active material is to overcome poor \\ conductivity and to increase stability of the electrodes during charging and discharging. The nanocomposites were \\ produced by sol-gel method, which allows producing very fine particle size of $\mathrm{LiMn}_{2} \mathrm{O}_{4} \cdot \mathrm{LiMn}_{2} \mathrm{O}_{4}$ and $\mathrm{LiMn}_{2} \mathrm{O}_{4}$ / \\ MWCNT were uniformly coated on an Al-foil to obtain $500 \mu \mathrm{m}$ thicknesses with a specific amount of binder and \\ conducting agent. The surfaces of cathodes were coated with $\mathrm{ZnO}$ by using magnetron sputtering PVD with a \\ thickness of $10 \mathrm{~nm}$. Coin-type (CR2016) test cells were assembled, directly using the $\mathrm{LiMn}_{2} \mathrm{O}_{4} / \mathrm{MWCNTs}$ and \\ surface coated $\mathrm{LiMn}_{2} \mathrm{O}_{4} /$ MWCNTs as anode and a lithium metal foil as the counter electrode.
}

DOI: $10.12693 /$ APhysPolA.125.331

PACS: 82.47.Aa, 81.05.Mh, 81.20.Fw, 68.47.Gh

\section{Introduction}

In the $\mathrm{Li}$-ion batteries, $\mathrm{LiCoO}_{2}, \mathrm{LiNiO}_{2}, \mathrm{LiFePO}_{4}$ and $\mathrm{LiMn}_{2} \mathrm{O}_{4}$ are considered most important cathode materials [1, 2]. Unlike $\mathrm{LiCoO}_{2}, \mathrm{LiNiO}_{2}$ and $\mathrm{LiFePO}_{4}$, spinel $\mathrm{LiMn}_{2} \mathrm{O}_{4}$ has become promising energy source and does not contain heavy metals to dispose after usage [3].

Furthermore, $\mathrm{LiMn}_{2} \mathrm{O}_{4}$ batteries have advantages as their low cost, abundant resource, easy preparation [4]. Despite the advantages, $\mathrm{LiMn}_{2} \mathrm{O}_{4}$ batteries suffer from capacity fading which restricts their commercial usage. This capacity fading results from: (I) dissolution of $\mathrm{Mn}^{2+}$, (II) the Jahn-Teller distortion, and (III) decomposition of electrolyte solution on the electrode. $\mathrm{Mn}^{2+}$ ion dissolution into the electrolyte, which occurs because of the reaction in the interface between electrolyte and electrode, is considered a main source of capacity fading $[4,5]$. To address disadvantages, doping different cations into spinel $\mathrm{LiMn}_{2} \mathrm{O}_{4}$ [6], surface treatment of the cathode with pure stable metals and metal oxides are most promising methods [7-9]. Multiwalled carbon nanotubes (MWCNTs) have unique one-dimensional tubular structure, high electrical conductivity, and large surface area, and have been considered an ideal nanomaterial to functionalize other materials for applications in energy conversion and storage. Therefore, electrical conductivity of the $\mathrm{LiMn}_{2} \mathrm{O}_{4}$ battery increases while decreasing the charging resistance. Hybrid nanostructures composed of MWCNTs, and active materials possess not only the inherent properties of nanocrystals and MWCNTs acting alone, but also additional, unique properties that arise from the electrical and thermal interactions between them [10].

In this study, it is aimed to determine calcination temperature and $\mathrm{ZnO}$ surface coating effects on the elec- trochemical properties in the $\mathrm{LiMn}_{2} \mathrm{O}_{4}$ and $\mathrm{LiMn}_{2} \mathrm{O}_{4} /$ MWCNT nanocomposite by using citric acid sol-gel method. Although there were several studies in the open literature, applying cathode surface coating with metal oxide and gold, there is no comprehensive study to show both surface coating and MWCNTs reinforcement effectstogether.

\section{Experiment details}

The $\mathrm{LiMn}_{2} \mathrm{O}_{4}$ powders were produced by using a well-known sol-gel method. The precursor materials were high-purity $\mathrm{Mn}\left(\mathrm{CH}_{3} \mathrm{COO}\right)_{2} \cdot 4 \mathrm{H}_{2} \mathrm{O}, \quad \mathrm{LiCH}_{3} \mathrm{COO} \cdot 2 \mathrm{H}_{2} \mathrm{O}$ and citric acid as a chelating agent. These precursors were dissolved in distilled water, and ammonia added to maintain $\mathrm{pH}$ between 7 and 10 . Then the obtained solution was heated with vigorous stirring to remove excess ammonia and water. The resultant gel was dried at $120^{\circ} \mathrm{C}$ for $10 \mathrm{~h}$ and calcinated at the temperatures of $300^{\circ} \mathrm{C}, 500{ }^{\circ} \mathrm{C}$ and $700^{\circ} \mathrm{C}$ for $24 \mathrm{~h}$ in air to determine the effect of calcination temperature on nanocrystalline structure and cell performance. The nanocomposites of $\mathrm{LiMn}_{2} \mathrm{O}_{4}$ reinforced with 5 wt\% MWCNT was prepared by mechanical alloying. MWCNTs and $\mathrm{LiMn}_{2} \mathrm{O}_{4}$ powders was placed in $80 \mathrm{ml}$ stainless steel mixing jars containing steel milling balls of $10 \mathrm{~mm}$ diameter (giving an initial ball-to-powder weight ratio $(\mathrm{BPR})=$ 15:1). The jars were agitated using a high-energy planetary ball mill (Fritsch Pulverisette F7) at $500 \mathrm{rpm}$ for milling time of $1 \mathrm{~h}$. For electrode preparation, $70 \mathrm{wt} \%$ $\mathrm{LiMn}_{2} \mathrm{O}_{4}$ powders were mixed with $20 \mathrm{wt} \%$ acetylene black (conducting agent), and $10 \mathrm{wt} \%$ polyvinylidene fluoride (binder-PVDF). Excess was 1-methyl-2-pyrrolidone (NMP). The slurry was uniformly coated on an Al-foil to obtain $500 \mu \mathrm{m}$ thicknesses. The surfaces of some selected bare cathodes and nanocomposites were coated 
with $\mathrm{ZnO}$ by magnetron sputtering method with thickness of $10 \mathrm{~nm}$.

A Rigaku (D/MAX/2200)X-ray diffraction (XRD) with a grazing incidence attachment and $\mathrm{Cu} K_{\alpha}$ radiation was used. The diffraction patterns were registered in the step scan mode, with a beam incidence angle of $0.5^{\circ}$, and recorded at $2^{\circ}(2 \theta)$ steps with a constant time of 1 min per step. Scanning electron microscopy (SEM) (JEOL 6060LV) has been used to determine morphologies of the nanocomposite electrodes. Coin-type (CR2016) test cells were assembled in an argon-filled glove box, directly using the $\mathrm{LiMn}_{2} \mathrm{O}_{4}$ and $\mathrm{LiMn}_{2} \mathrm{O}_{4} / \mathrm{MWCNTs}$. The cells were cyclically tested on a MTI-BST 8 battery tester using $0.4 \mathrm{C}$ over a voltage range of $3.0-4.3 \mathrm{~V}$. All tests were performed at room temperature $\left(25^{\circ} \mathrm{C}\right)$. The electrochemical impedance spectroscopy (EIS) was carried out by applying an ac voltage of $10 \mathrm{mV}$ over the frequency range from $1 \mathrm{~Hz}$ to $1000 \mathrm{kHz}$ (Gamry Instrument Version 5.67).

\section{Results and discussions}

Figure 1 presents $\mathrm{LiMn}_{2} \mathrm{O}_{4}$ powders surface morphology at different temperatures (a, c, d) and nanocomposite of $\mathrm{LiMn}_{2} \mathrm{O}_{4} / \mathrm{MWCNT}$ calcinated at $300^{\circ} \mathrm{C}$ (b). $500{ }^{\circ} \mathrm{C}$ and $700{ }^{\circ} \mathrm{C}$ calcinated reinforced powders are not shown because the microstructure of all MWCNT reinforced samples after grinding is very similar to each other. It can be seen from the SEM images that $\mathrm{LiMn}_{2} \mathrm{O}_{4}$ powders are fine particles and have homogeneous morphology. SEM images indicate that grain sizes of $\mathrm{LiMn}_{2} \mathrm{O}_{4}$ powders increase with increasing calcination temperatures. However, because of using citric acid sol-gel method, $\mathrm{LiMn}_{2} \mathrm{O}_{4}$ powders still have small particle size even at calcination temperature of $700{ }^{\circ} \mathrm{C}$. This was caused from faster growing speed and agglomerated areas turn into large particles with temperature $[11,12]$. MWCNTs, marked in Fig. 1b, were dispersed into $\mathrm{LiMn}_{2} \mathrm{O}_{4}$ nanopowders as a network in all reinforcedpowders.

Figure 2 shows discharge capacities of the bare $\mathrm{LiMn}_{2} \mathrm{O}_{4}, \mathrm{LiMn}_{2} \mathrm{O}_{4} / \mathrm{MWCNT}$ electrodes after calcination at 300,500 , and $700^{\circ} \mathrm{C}$ and cyclically tested at room temperature. The electrodes calcinated at 300 and $500{ }^{\circ} \mathrm{C}$ show similar initial capacities and the capacity fading rates (Fig. $2 \mathrm{a}$ and b). The bare $\mathrm{LiMn}_{2} \mathrm{O}_{4}$ shows high initial capacity but the cell performance exhibits very sharp decrease in the capacity with increasing cycle number. Coating of $\mathrm{LiMn}_{2} \mathrm{O}_{4}$ electrode surfaces with magnetron sputtering yields higher discharge capacities for the initial cycles and also prevented the decrease of capacity with increasingcycles.

Introducing $5 \mathrm{wt} \%$ MWCNTs into $\mathrm{LiMn}_{2} \mathrm{O}_{4}$ results to increase both initial capacity and capacity retention with increasing cycle for all calcination temperature conditions. When the $\mathrm{LiMn}_{2} \mathrm{O}_{4}$ was reinforced with MWCNTs and coated with $\mathrm{ZnO}$, produced excellent capacity retentions. In these composites, the capacity retention was

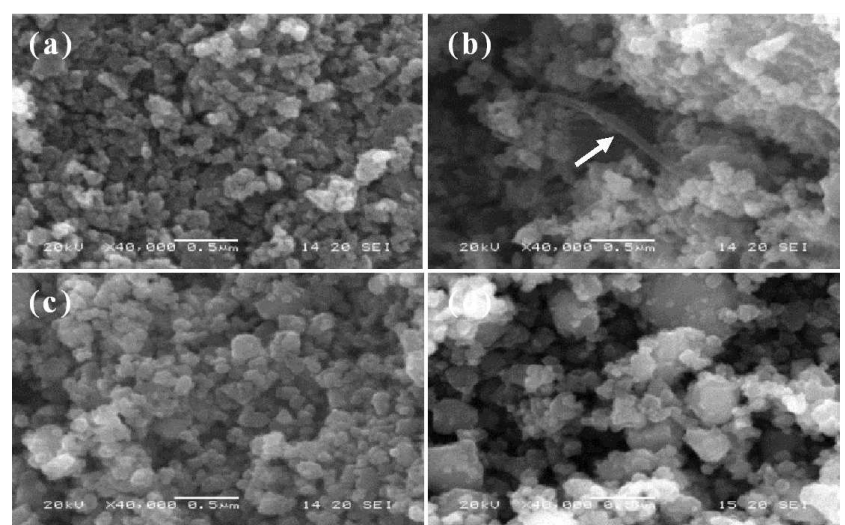

Fig. 1. SEM photographs of (a) $300{ }^{\circ} \mathrm{C}$ calcinated $\mathrm{LiMn}_{2} \mathrm{O}_{4}$, (b) $300{ }^{\circ} \mathrm{C}$ calcinated $\mathrm{LiMn}_{2} \mathrm{O}_{4} / \mathrm{MWCNT}$ nanocomposite, (c) $500{ }^{\circ} \mathrm{C}$, and (d) $700{ }^{\circ} \mathrm{C}$ calcinated $\mathrm{LiMn}_{2} \mathrm{O}_{4}$ nanopowders after grinding.
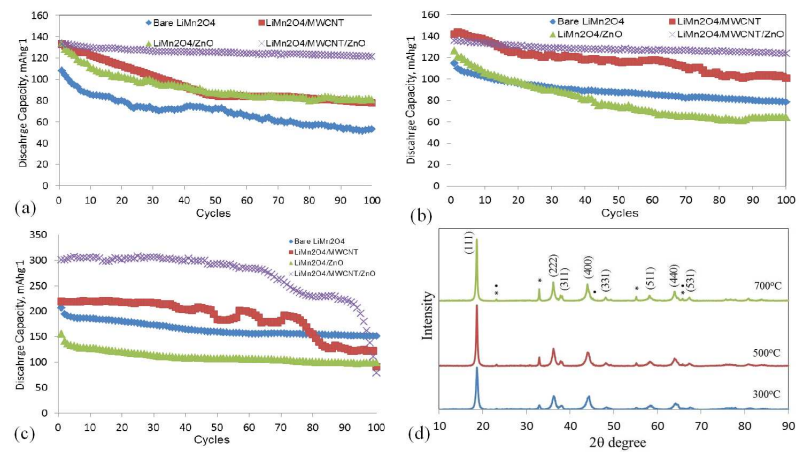

Fig. 2. Discharge capacity versus cycle number for $\mathrm{LiMn}_{2} \mathrm{O}_{4}$ and nanocomposites calcinated at (a) $300{ }^{\circ} \mathrm{C}$, (b) $500{ }^{\circ} \mathrm{C}$, (c) $700{ }^{\circ} \mathrm{C}$, and (d) XRD patterns of nanocomposites calcinated at three different temperatures $\left(\mathrm{LiMn}_{2} \mathrm{O}_{4}, * \mathrm{Mn}_{2} \mathrm{O}_{3}, \bullet \mathrm{Li}_{2} \mathrm{MnO}_{3}\right)$.

calculated as $95 \%$ even at the 100th cycle. This high capacity retention is attributed to the combined effects of high conductivity emanated from MWCNTs and surface coating with $\mathrm{ZnO}$, which prevents dissolution of the $\mathrm{Mn}$ into the electrolyte.

However, the electrodes calcinated at $700{ }^{\circ} \mathrm{C}$ show dissimilar characteristics depending on the increased amount of $\mathrm{Mn}_{2} \mathrm{O}_{3}$ and formation of layered $\mathrm{LiMn}_{2} \mathrm{O}_{3}$ as can also be seen in the XRD analysis. In these electrodes, very high initial discharge capacities were obtained.

For example, the initial capacity of the electrode

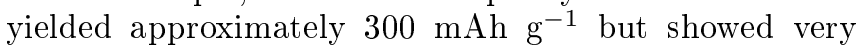
high capacity fading after 90th cycle and almost failed in the 100th cycle (Fig. 2c). Theoretically, $\mathrm{LiMn}_{2} \mathrm{O}_{4}$ has $148 \mathrm{mAh} \mathrm{g}^{-1}$ discharge capacity [13]. However, it is believed that increasing the calcination temperature resulted in increase of amount of layered $\mathrm{LiMn}_{2} \mathrm{O}_{3}$ structure.

In recent years, it was reported that Li-excess layered oxides have a very high discharge capacity, but 
have many problems such as voltage instability, capacity fading and slow charge/discharge rate preventing them from commercialization [14]. Increasing discharge capacity and/or cycle number resulted in very high capacity fading in the layered type of the cathode materials.

The XRD analysis of the nanocomposites at three different calcination temperatures is presented in Fig. 2d. Layered $\mathrm{Li}_{2} \mathrm{MnO}_{3}$ and $\mathrm{Mn}_{2} \mathrm{O}_{3}$ impurity peaks were observed [15]. XRD peaks of $300^{\circ} \mathrm{C}$ showed broadening, which indicates smaller grain size and micro stretching [16]. When the calcination temperature is increased to $700^{\circ} \mathrm{C}$, XRD peaks showed to have sharpened characteristic, which indicates larger grain size and higher crystallinity [11]. The average dimension of crystallites $d$ was estimated from the linewidths of XRD reflections. It was calculated that grain sizes at $300{ }^{\circ} \mathrm{C}, 500^{\circ} \mathrm{C}$, and $700^{\circ} \mathrm{C} \mathrm{LiMn}_{2} \mathrm{O}_{4}$ were found approximately $22.13,23.89$, and $29.23 \mathrm{~nm}$, respectively. Lattice parameters calculated from the patterns are found to be $8.569 \AA$ for $300{ }^{\circ} \mathrm{C} \mathrm{LiMn}_{2} \mathrm{O}_{4}$ and $8.386 \AA$ both for $500^{\circ} \mathrm{C}$ and $700{ }^{\circ} \mathrm{C}$ $\mathrm{LiMn}_{2} \mathrm{O}_{4}$. Lattice parameter for $\mathrm{LiMn}_{2} \mathrm{O}_{4}$ was reported as 8.206-8.251 $\AA$ in literature [17]. Increasing lattice constant can be attributed to $\mathrm{Mn}^{4+}$ ion transitions to $\mathrm{Mn}^{3+}$ in high spinstate.

Addition of $5 \mathrm{wt} \%$ MWCNT to $\mathrm{LiMn}_{2} \mathrm{O}_{4}$ nanopowders did not show significant change on grain size and lattice parameter at $300^{\circ} \mathrm{C}$. But, for higher calcination temperatures, grain size and lattice parameter values are differed. 5 wt\% MWCNT reinforced powders grain size were calculated and found to be $29.23 \mathrm{~nm}$ and $38.22 \mathrm{~nm}$ at $500{ }^{\circ} \mathrm{C}$ and $700^{\circ} \mathrm{C}$ calcination temperatures, respectively. For $500{ }^{\circ} \mathrm{C}$ and $700^{\circ} \mathrm{C}$, MWCNT addition decreased lattice parameters to 8.23 and 8.24 , respectively. The reason of decrease in the lattice parameter is increase in total atom or ions ratio in the surface when compared with the total ions or ions in the crystal [18].
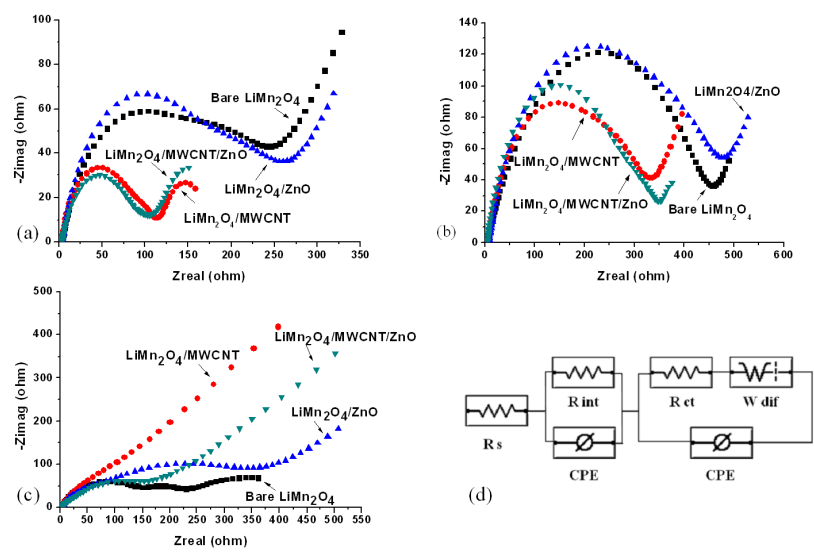

Fig. 3. EIS spectra for $\mathrm{LiMn}_{2} \mathrm{O}_{4}$ and nanocomposites calcinated at (a) $300{ }^{\circ} \mathrm{C}$, (b) $500{ }^{\circ} \mathrm{C}$, (c) $700{ }^{\circ} \mathrm{C}$, and (d) the equivalent circuitmodel.

In Fig. 3, the Nyquist plots, and the equivalent circuit model is presented. On this circuit, $R_{\mathrm{s}}$ is the resistance associated with the electrolyte and cell component, $R_{\text {int }}$ is the resistance of any film formation on the cathode surface (first $\mathrm{HF}$ semicircle), $R_{\mathrm{ct}}$ is the charge-transfer resistance of the electrode reaction with lithium ions (middle frequency semicircle), and $W_{\text {dif }}$ is the resistance of the lithium ion diffusion to the electrode (low frequency semi circle) [19]. The $R_{\mathrm{ct}}$ results are presented inTable before testing the electrochemical performances.

Electrochemical impedance parameters of calculated from equivalent circuitmodel.

TABLE

\begin{tabular}{c|c|c|c|c|c}
\hline \hline Samples & $R_{\mathrm{ct}}$ & Samples & $R_{\mathrm{ct}}$ & Samples & $R_{\mathrm{ct}}$ \\
\hline $300{ }^{\circ} \mathrm{C} /$ bare & 448.1 & $500{ }^{\circ} \mathrm{C} /$ bare & 115 & $700{ }^{\circ} \mathrm{C} /$ bare & 146 \\
$300{ }^{\circ} \mathrm{C} / \mathrm{MWCNT}$ & 190.3 & $500{ }^{\circ} \mathrm{C} / \mathrm{MWCNT}$ & 31.01 & $700{ }^{\circ} \mathrm{C} / \mathrm{MWCNT}$ & 108.4 \\
$300^{\circ} \mathrm{C} / \mathrm{ZnO}$ & 339 & $500{ }^{\circ} \mathrm{C} / \mathrm{ZnO}$ & 129 & $700{ }^{\circ} \mathrm{C} / \mathrm{ZnO}$ & 296.8 \\
$300{ }^{\circ} \mathrm{C} / \mathrm{MWCNT} \mathrm{ZnO}$ & 266.7 & $500{ }^{\circ} \mathrm{C} / \mathrm{MWCNT} \mathrm{ZnO}$ & 35.15 & $700^{\circ} \mathrm{C} / \mathrm{MWCNT} \mathrm{ZnO}$ & 140
\end{tabular}

It can be seen from Fig. 3 that for all the calcination temperatures condition, introducing MWCNT into $\mathrm{LiMn}_{2} \mathrm{O}_{4}$ seems to be very effective to decrease the charge transfer resistance. This is attributed to the increased conductivity and amount of Li ions absorption emanated from MWCNTs [10].

It is well known that the semicircle corresponding to the passivation film formed by the reaction between the oxide and electrolyte [20]. The decrease of the diameter in the semicircle is seen for all the nanocomposite electrodes, produced by introducing MWCNTs.
Literature about EIS reports that a circle at the high-to-middle frequency semicircle represents the resistance for the Li-ions migration through the EIS layer and film capacitance. Another semicircle at the low-frequency semicircle is related to charge transfer resistance and interfacial capacitance between the electrode and electrolyte interface, and the slopping straight line at very low frequency corresponds to the Li-ions diffusion in the bulk materials. The intercept of the high-frequency semicircle on the real axis ( $z$ real axis) represents resistance contribution coming from the electrolyte solution [21]. 
According to the EIS results obtained in this study, they evidenced that coating the surfaces of the nanocomposite electrodes with $\mathrm{ZnO}$ magnetron sputtering resulted in a small increase in the charge transfer resistance. This is because coating the surfaces of electrodes causes to increase the surface tension and prevents the electrolyte impregnation at the initial stages. As shown in the discharge capacity results versus the cycle number (Fig. 3), these surface coated electrodes showed higher capacity retention and thus, less capacity fading. Therefore, from the EIS results, it can be concluded that MWCNT addition and coating the electrode surfaces with a $10 \mathrm{~nm} \mathrm{ZnO}$ provided very attractive results to prevent $\mathrm{Mn}$ dissolution into the electrolyte. It can be speculated that the surface coating of $\mathrm{ZnO}$ suppressed the formation of passivation on the surface of the $\mathrm{LiMn}_{2} \mathrm{O}_{4}$, preventing the electrolyte decomposition which leads to the dissolution of the $\mathrm{Mn}$ ion.

\section{Conclusions}

Citric acid sol-gel method was used to produce $\mathrm{LiMn}_{2} \mathrm{O}_{4}$ electrodes at $300^{\circ} \mathrm{C}, 500{ }^{\circ} \mathrm{C}$, and $700{ }^{\circ} \mathrm{C}$ calcination temperatures. Introducing $5.0 \mathrm{wt} \% \mathrm{MWCNT}$ into $\mathrm{LiMn}_{2} \mathrm{O}_{4}$ increased discharge capacity of the $\mathrm{LiMn}_{2} \mathrm{O}_{4}$ and as high as $95 \%$ capacity retention values were obtained even after 100 cycles. Increasing the calcination temperatures resulted in producing both $\mathrm{Li}_{2} \mathrm{MnO}_{3}$ and $\mathrm{Mn}_{2} \mathrm{O}_{3}$ together with spinel $\mathrm{LiMn}_{2} \mathrm{O}_{4}$. Since the $\mathrm{Li}_{2} \mathrm{MnO}_{3}$ has layered structure, the initial discharge capacity was obtained very high $\left(300 \mathrm{mAh} \mathrm{g}^{-1}\right)$ but decreased rapidly by increasing cycle number. $\mathrm{ZnO}$ coatings on $\mathrm{LiMn}_{2} \mathrm{O}_{4} / \mathrm{MWCNT}$ nanocomposites with $10 \mathrm{~nm}$ thickness increased the discharge capacity and provided excellent capacity retention. EIS measurements showed that MWCNT addition provides the decrease in charge transfer resistance.

\section{Acknowledgments}

The authors thank the Scientific and Technological Research Council of Turkey (TÜBİTAK) for their financial support under the contract number of 111M021.

\section{References}

[1] B. Xu, D. Qian, Z. Wang, Y.S. Meng, Mater. Sci. Eng. R 73, 51 (2012).

[2] M.G. Kim, J. Cho, Adv. Funct. Mater. 19, 1497 (2009).
[3] H. Sun, Y. Chen, C. Xu, D. Zhu, L. Huang, J. Solid State Electrochem. 16, 1247 (2012).

[4] W. Tang, L. Liu, Y. Zhu, H. Sun, Y. Wu, K. Zhu, Energy Environ. Sci. 5, 6909 (2012).

[5] Q. Liu, Sh. Wang, H. Tan, Z. Yang, J. Zeng, Energies 6, 1718 (2013).

[6] H.L. Li, S.J. Bao, Y.Y. Liang, W.J. Zhou, B.L. He, J. Colloid Interface Sci. 300, 633 (2006).

[7] H. Şahan, H. Göktepe,Ş. Patat, J. Mater. Sci. Technol. 27, 415 (2011).

[8] M. Prabu, M.V. Reddy, S. Selvasekarapandian, S. Admas, K.P. Loh, G.V. Subba Rao, B.V.R. Chowdari, J. Electrochem. Soc. 160, A3144 (2013).

[9] T.F. Yi, Y.R. Zhu, X.D. Zhu, J. Shu, C.B. Yue, A.N. Zhou, Ionics 15, 779 (2009).

[10] X.M. Liu, Z.D. Huang, S. Oh, P.C. Ma, P.C.H. Chan, G.K. Vedam, K. Kang, J.K. Kim, J. Power Sources 195, 4290 (2010).

[11] Y.K. Sun,I.-H. Oh, K.Y. Kim, Ind. Eng. Chem. Res. 36, 4839 (1997).

[12] M.W. Wu, X.H. Li, Z.B. Xiao, J. Liu, W.B. Yan, M.Y. Ma, Mater. Chem. Phys. 84, 182 (2004).

[13] M.B. Sassin, S.G. Greenbaum, P.E. Stallworth, A.N. Mansour, B.P. Hahn, K.A. Pettigrew, D.R. Rolison, J.W. Long, J. Mater. Chem. A 1, 2431 (2013).

[14] N. Yabuuchi, K. Yoshii, S.T. Myung, I. Nakai, S. Komaba, J. Am. Chem. Soc. 133, 4404 (2011).

[15] B.J. Hwang, R. Santhanam, D.G. Liu, J. Power Sources 97-98, 443 (2001).

[16] M. Alaf, D. Gultekin, H. Akbulut, Appl. Surf. Sci 275, 244 (2013).

[17] M. Michalska, L. Lipinska, R. Diduszko, M. Mazurkiewicz, A. Malolepszy, L. Stobinski, K.J. Kurzydlowski, Phys. Status Solidi C 7-8, 2538 (2011).

[18] N. Kamarulzaman, R. Yusoff, N. Kamarudin, N.H. Shaari, N.A. Abdul Aziz, M.A. Bustam, N. Blagojevic, M. Elcombe, M. Blackford, M. Avdeev, A.K. Arof, J. Power Sources 188, 274 (2009).

[19] S. Yang, J. Huo, H. Song, X. Chen, Electrochim. Acta 53, 2238 (2008).

[20] H. Liu, C. Cheng, Zongqiuhu, K. Zhang, Mater. Chem. Phys. 101, 276 (2007).

[21] J. Tu, X.B. Zhao, G.S. Cao, J.P. Tu, T.J. Zhu, Mater Lett. 60, 3251 (2006). 